\title{
BACKGROUND OF AND REPORT ON THE 1988 MEETING OF THE ASSOCIATION OF NORTH AMERICAN PALEONTOLOGICAL SOCIETIES (ANAPS) AND THE ORGANIZATION OF NORTH AMERICAN PALEONTOLOGICAL CONVENTIONS (NAPCs)
}

For several years, representatives of various U.S. and Canadian professional paleontological societies have been meeting at the Annual Meeting of the Paleontological Society to discuss the functions of an umbrella group for the profession known as ANAPS (Association of North American Paleontological Societies). These society representatives agreed that one of the major functions of ANAPS would be to help organize NAPCs (North American Paleontological Conventions). In particular, various societies desire to organize interdisciplinary symposia, workshops, etc. at NAPCs, in which such seemingly different approaches as applied palynology and descriptive vertebrate paleontology would be included in the same symposium. Various of the societies believe that NAPCs should be organized so that half the program is arranged by paleontologists in the host city and host institutions, and the other half of the program should be arranged by societies; other sets of percentages that have been discussed are $40-60$ and 60-40. Whatever sets of percentages are decided upon, it seems clear that the various North American professional societies desire to help develop and prepare the programs for NAPCs. Other ideas for NAPCs discussed at ANAPS meetings include sessions for technical support staff such as preparators, photographers, etc. of fossils, and special symposia and workshops for amateur paleontologists.

NAPCs are self supporting financially, and one NAPC is expected to provide start-up funds for the next NAPC. Following NAPC-III, in Montreal, the organizers of that convention sent the startup funds for NAPC-IV to The Paleontological Society (PS). These funds were kept in a separate interest-bearing account by the PS, until the site of NAPC-IV was chosen, at which time the funds were turned over to the NAPC-IV organizing committee. After NAPC-IV, the startup funds for NAPC-V were again sent to the PS to be held in a separate interest-bearing account for NAPC-V.

On November 8, 1988, representatives of the various North American professional paleontological societies met in Denver, Colorado, at the Annual Meeting of the PS, at the request of the Chairman of ANAPS, Don L. Eicher. Present at the meeting were representatives from the American Association of Stratigraphic Palynologists; Cushman Foundation for Foraminiferal Research; North American Micropaleontology Section; Paleontological Division, Geological Association of Canada; Paleontological Research Institution; Paleobotanical Section, Botanical Society of America; Paleontological Society; Society of Economic Paleontologists and Mineralogists; and Society of Vertebrate Paleontology. Subsequent to the Denver Meeting, the Canadian Association of Palynologists contacted Chairman Eicher, and requested "to receive any communication or correspondence resulting from this" meeting.

Most of the November 8, 1988, meeting of ANAPS was devoted to a proposal from paleontologists in the Chicago area to hold NAPC-V in that city in 1992, probably from late June to early July. Discussions on this proposal were wideranging, including the choice of date; symposia organized by each society; field trips to be organized by the societies; involvement of the societies in planning NAPC-V; themes, short courses, and symposia arranged by the Chicago organizers of NAPC-V; publication of abstracts, but not proceedings; costs of meeting in Chicago; how to involve the amateur community in the convention; contacts with Mexican paleontologists, etc. Toward the end of the meeting, on motion of Pojeta, seconded Flynn, passed unanimously, ANAPS accepted the proposal of the Chicago area paleontologists to host NAPC-V in that city in the early summer of 1992 , at the time of the centenaries of both the Field Museum of Natural History and the University of Chicago. Along with the acceptance of the Chicago paleontologists' proposal, ANAPS instructed the PS to turn over the approximately $\$ 6,000$ of start-up money available from NAPC-IV.

At the Annual Meeting of The Paleontological Society, in St. Louis, Missouri, on Monday, November 6, 1989, the PS will again host a meeting of society representatives to ANAPS. NAPC-V will again be the major agenda item, and it is desired that each member society of ANAPS will have fairly firm program suggestions to present to Peter Crane, Field Museum of Natural History, and Vice Chairman of ANAPS.

Paleontological Society members with suggestions for program items for NAPC-V should contact Peter M. Sheehan, Incoming Program Coordinator, Department of Geology, Milwaukee Public Museum, Milwaukee, Wisconsin 53233. Members interested in working with the amateur paleontologists' program should contact N. Gary Lane, Past-President, Department of Geology, Indiana University, Bloomington, Indiana 47401. Other PS representatives to ANAPS who can be contacted are John Pojeta, Jr., President-Elect, U.S. Geological Survey, National Center, MS 970, Reston, Virginia 22092, and Donald L. Wolberg, Secretary, New Mexico Bureau of Mines and Mineral Resources, Campus Station, Socorro, New Mexico 87801.

Respectfully submitted, JOHN POJETA, JR.

Secretary/Treasurer ANAPS 